\title{
Analysis of humoral immune response of animals exposed to bacterial antigens
}

\author{
PALLVARNANATHASAMY DHASARATHAN ${ }^{l}$, PUGAZHENTHI M. $^{1}$, VALIVITTAN K. $^{2}$
}

${ }^{1}$ Prathyusah Institute of Technology and Management, Thiruvallur, India

${ }^{2}$ Department of Biotechnology, St Peter's University, Avadi, Chennai, India

\begin{abstract}
From the Aeromonas hydrophila strain, five different types of antigens such as heat killed antigen, whole cell antigen, heat killed antigen with antiserum, whole cell antigen with antiserum and nucleotide antigens were prepared and injected into the experimental fish (Catla catla) groups for the study of immunomodulation. Analysis of immunogenicity of antigens against the fish Catla catla was estimated. The A. hydrophila produced $\beta$ hemolytic pattern on the blood agar plate. B lymphocyte counts using rosette forming assay revealed a significant decrement in pathogens exposed fishes as compared to controls. Fishes exposed to pathogenic strains (1/10 th sublethal concentration) for 3 weeks showed a reduction in $P F C$. The effect or pathogenic antigens in direct spleenic plaque forming cells (1 g M producing cells) showed a reduction in the secondary plaque forming cell in the first 3 weeks and a time-and dose-dependent decrease in primary and secondary PFC response. A remarkable observation enhancement in $B$ cell production due to immune complex of antigens was noted in the present study. The enhancement of this type of immune responses confirms the potential of immune complexes to be used as vaccines.
\end{abstract}

Key words: vaccine, immunity, pathogen.

(Centr Eur J Immunol 2014; 39 (3): 323-326)

\section{Introduction}

The humoral defense mechanism involves the production of antibodies and is an important mechanism to prevent bacterial disease. The fish antibodies function as antitoxins, anti-adhesions, and anti-invasions. Antibodies also activate the classical complement system [1]. Toxins produced and secreted by bacteria are efficiently neutralized when antibodies bind to them. To prevent bacterial adherence to fish epithelial cells, antibodies function as anti-adhesins by binding to the adhesins on the bacterial surface. Anti-adhesin antibodies are found in the mucosal layers of the skin, gut, and gills [1]. Anti-invasions are used to prevent bacterial invasion of non-phagocytic cells. Bacteria invade non-phagocytic cells to evade the immune response of the host. Antibodies functioning as anti-invasions prevent bacterial invasion of host cells allowing phagocytic cells to remove the bacteria. Moreover, antibodies bound to bacterial surfaces can activate the classical complement system.

B cells play an important role in the humoral immunity. Together with the T cells, they make up the third line of defense differentiating into specialized antibody producing plasma cells and memory cells after activation $[2,3]$. In the present study, screening of stimulation of humoral immune response in fish, Catla catla, administered with a bacterial antigen was performed.

\section{Material and methods}

\section{Immunization}

Six groups of experimental fishes were maintained. Five groups of fishes were immunized with $1 \mathrm{ml}$ of five different antigens (whole cell antigen, whole cell bacterial antigen with antiserum, heat killed antigen, heat killed antigen with antiserum, nucleotide antigen) of Aeromonas hydrophila through intraperitoneal injection using $1 \mathrm{ml}$ glass syringe with 24 gauge needle. The fish was held with lateral facing the investigator. The needle was inserted about half a centimeter just above the peritoneal cavity (which can be confirmed by the free movement of the free end). A group of fishes used as controls had received the same amount of saline.

\section{Serial bleeding}

The fishes were bled serially using $1 \mathrm{ml}$ tuberculin syringe with 24 gauge needle from the common cardinal vein situated just below the gills [4] at regular intervals of seven days for antibody response till the $28^{\text {th }}$ day; intervals of 2 days for lysozyme and neutrophil assay till the

Correspondence: Pallvarnanathasamy Dhasarathan, PhD, Prathyusah Institute of Technology and Management, Thiruvallur, India, e-mail: dhasa_rathan@yahoo.co.in 
$10^{\text {th }}$ day. For bleeding, the fish was held in the left hand with the right side of the fish facing the investigator. The operculum was lifted and kept open by the left hand thumb. A metal rod ( $3 \mathrm{~mm}$ diameter and $12 \mathrm{~cm}$ long) was used to lift the gill lamellae in order to expose the common cardinal vein. From the common cardinal vein, nearly $0.2-$ $0.3 \mathrm{ml}$ of blood was collected from each fish using $1 \mathrm{ml}$ glass tuberculin syringe fitted with 24 gauge needle. The whole procedure from the handling of the fish to the end of the bleeding process took only $30-40$ seconds causing minimal trauma to the fish. Quick and gentle handling of fish is required to avoid stress which is known to suppress the immune system. Antigen administration and serial bleeding were always done between 14 hours and 16 hours to avoid possible influence of cardiac rhythmic variation on the immune response. The blood drawn was collected in Eppendorf tubes.

\section{Antiserum collection}

Blood collected from immunized and normal fish was kept at room temperature for 15 minutes. The clot was freed from the wall of the micro centrifuge tube for efficient retraction and kept overnight at $4^{\circ} \mathrm{C}$. The serum was separated by spinning down the clot at $3000 \mathrm{rpm}$ for 15-20 minutes and collected in sterilized vials. The serum was stored in the freezer at $-20^{\circ} \mathrm{C}$ until use. In the present study, humoral immune response was analyzed by antibody titration. B cells rosette assay and plaque forming cell assay techniques were carried out. The test fish, Catla catla, were divided into 6 groups (each group contains 6 animals) and treated with different types of antigen (one group served as control) prepared from A. hydrophila.

\section{Screening of antibody}

From the normal and antigen treated fishes, five $\mathrm{ml}$ of blood sample was collected and serum separated for antibody screening. Quantization of serum antibodies was carried out by the antibody titre plate technique containing respective antigens. $25 \mu \mathrm{l}$ of physiological saline was added into all wells of microtitre plate, then $25 \mu$ of antiserum was added into the first well of microtitre plate, the antiserum was seriously diluted in the well of the first row till the $11^{\text {th }}$ well of the microtitre plate leaving the $12^{\text {th }}$ well as positive control. Then, $25 \mu \mathrm{l}$ of $1 \%$ test antigen in saline was added to all the wells of the microtitre plate. The plate was hand shaken for the effective mixing of reagents and incubated for an hour at $37^{\circ} \mathrm{C}$. The highest dilution of serum samples which shows detectable agglutination was recorded and expressed in $\log _{2} 2$ titre of the serum.

\section{B cell erythrocyte assay}

Blood sample was collected from normal and antigen treated fishes and stored in heparin pretreated vials. B cell counts in the test blood samples were carried out using the following method. 5-10 $\mathrm{ml}$ of the blood was collected in a sterile conical flask containing 4-5 sterile glass beads. It was continuously swirled until no sounds from the conical flask were heard. This indicates that all fibrins have adhered to the beads. This blood was considered as defibrinated blood and was diluted with the equal volume of physiological saline. $3 \mathrm{ml}$ of lymphoprep solution was taken in a centrifuge tube using a Pasteur pipette. Care was taken so that the FICON layer of the lymphoprep solution present in the centrifuge tube was then centrifuged at $1600 \mathrm{rpm}$ for $20 \mathrm{~min}$. The interphase (containing lymphocytes) was removed using a pipette. The cells were washed with $1 \mathrm{ml}$ of saline and excess FICON was removed. The sample was again washed with $1 \mathrm{ml}$ of saline, after centrifugation, the supernatant was decanted by inverting the tube over a filter paper. After all saline was drained, the pellet was re-suspended in $300 \mu$ of RPMI 1640 medium.

Twelve to fourteen $\mathrm{cm}$ of a drinking straw was cut. One end of the straw was cut in slant and sealed by slightly heating the tip in a flame. Nylon wool fibers were finely teased using a pair of forceps and the teased fibers were packed loosely into a straw. Nylon wool was washed with $5 \mathrm{ml}$ of saline and then packed into a straw. A small opening was made at the sealed end of the straw to drain the physiological saline; the nylon wool was then filled with $3 \mathrm{ml}$ of RPMI 1640 medium in a horizontal position. The nylon wool column was kept in the incubator (at $37^{\circ} \mathrm{C}$ for 30 minutes) in horizontal position. This process activates the nylon wool column.

Resuspended lymphocytes were loaded into the activated nylon wool column. Then, the column was held vertically above an Eppendorf tube, now hot saline was passed and $\mathrm{T}$ cells are eluted to the Eppendorf tube. Cold saline was poured into the column and was gently squeezed to release the adhered $\mathrm{B}$ cells. The cold saline dripping out of the column was collected in another Eppendorf tube. $0.2 \mathrm{ml}$ of the saline containing B lymphocytes (from the Eppendorf tube containing B cells) was taken in a separate Eppendorf tube. To this $0.2 \mathrm{ml}$ of $1 \%$ SRBC was added and then the mixture was centrifuged for 12 minutes at $16,000 \mathrm{rpm}$. After centrifugation, the samples were incubated in an ice box or refrigerator at $4^{\circ} \mathrm{C}$ for 5 minutes. After cold incubation the pellet in the Eppendorf tube was re-suspended by gentle flushing with a Pasteur pipette. Then, a drop of it was taken on a clean dry slide to observe and enumerate B cells under microscope $(20 \times / 40 \times)$. The number of $B$ cell rosettes formed were observed per hundred lymphocytes observed.

\section{Plaque forming cell assay}

From the control and antigen treated fishes, spleen was aseptically dissected out. Spleen was teased with a needle to prepare the cell suspension in RPMI 1640 medium. The spleenic cell suspension was prepared separately from dif- 
ferent groups each and carefully marked for further analysis. Spleen cells were washed twice with RPMI 1640 media and suspended to a density of $1 \times 10^{4}$ cells $/ \mathrm{ml}$. Petri dishes $(2-5$ $\mathrm{cm}$ diameter) were layered with $1-2 \%$ agarose in $0.15 \mathrm{M}$ $\mathrm{NaCl}$. A mixture of $2 \mathrm{ml}$ of $0.6 \% \mathrm{SRBC}$ (v/v packed cell volume) and $1 \times 10^{6}$ spleen cells $0.1 \mathrm{ml}$ was poured over the base layer. Then, petri dishes were incubated at $37^{\circ} \mathrm{C}$ for $90 \mathrm{~min}$. Two $\mathrm{ml}$ of $1: 10$ diluted fresh Guinea pig serum was added to each petri dish as a complement. Incubation was further continued for 45 minutes. Plaques formed on the agarose surface were then counted and the values were expressed as counts per $10^{6}$ spleen cells.

\section{Results and discussion}

Humoral immunity is mainly mediated by serum antibodies which are the protein secreted by B cell compartment of immune responses. The reaction between anti- gen and antibody involve several steps like recognition, stimulation and neutralization. It has been analyzed by a different method of antigen antibody reactions which are presented here.

To optimize the serum dilution with saline, control serum was loaded over a range of dilution from $1: 1250$ to $1: 320$ and this appeared to be the highest antibody titre (Tables 1-3). An estimation of antibody levels in the serum after an antigenic challenge will expose the functioning of humoral immune systems. In immunodeficient animals, antibody production was affected and hence humoral response against a disease causing antigen was lower. But the immune complex treated animals enhance the production of antibodies. In the present study, pathogen and heat killed pathogen treated fishes showed an antibody suppressive effect. The suppression of antibody reflects the reduction of humoral immune response and this state is subject to easy infection. Immunomodulation of the whole

Table 1. Character analysis of Catla catla exposed to various types of antigens

\begin{tabular}{clccccc}
\hline $\begin{array}{c}\text { S. } \\
\text { No. }\end{array}$ & Character & $\begin{array}{c}\text { Heat killed } \\
\text { bacterial antigen }\end{array}$ & $\begin{array}{c}\text { Whole cell } \\
\text { bacterial antigen }\end{array}$ & $\begin{array}{c}\text { Heat killed } \\
\text { bacterial antigen } \\
\text { with antiserum }\end{array}$ & $\begin{array}{c}\text { Whole cell } \\
\text { bacterial antigen } \\
\text { with antiserum }\end{array}$ & $\begin{array}{c}\text { Nucleotide } \\
\text { antigen }\end{array}$ \\
\hline 1 & Weight of the animal $(\mathrm{gm})$ & 20 & 20 & 25 & 28 & 20 \\
\hline 2 & Movement of the animal & Resting & Abnormal & Restless & Abnormal & Abnormal \\
\hline 3 & Adulation days & 24 & 27 & 32 & 24 & 9 \\
\hline
\end{tabular}

Table 2. Enumeration of B cells using rosette forming assay in fish Catla catla exposed to different sublethal concentrations of $A$. hydrophila antigens

\begin{tabular}{|c|c|c|c|c|}
\hline \multirow[t]{2}{*}{$\begin{array}{l}\text { S. } \\
\text { No. }\end{array}$} & \multirow[t]{2}{*}{ A. hydrophila test antigens } & \multicolumn{3}{|c|}{$\begin{array}{l}\text { Number of B cells rosette formed in } 100 \text { lymphocytes observed at different } \\
\text { time intervals }\end{array}$} \\
\hline & & I week & II week & III week \\
\hline 1. & Control fishes & 18 & 18 & 18 \\
\hline 2. & Heat killed bacterial antigen & 8 & 6 & 9 \\
\hline 3. & Whole cell bacterial antigen & 8 & 7 & 9 \\
\hline 4. & Heat killed bacterial antigen with antiserum & 9 & 8 & 11 \\
\hline 5. & Whole cell bacterial antigen with antiserum & 6 & 6 & 8 \\
\hline 6. & Nucleotide antigen & 8 & 6 & 9 \\
\hline
\end{tabular}

Table 3. Plaque Forming Assay of fish Catla catla at different time intervals

\begin{tabular}{|c|c|c|c|c|}
\hline \multirow{2}{*}{$\begin{array}{c}\text { S. } \\
\text { No. }\end{array}$} & \multirow[t]{2}{*}{ A. hydrophila test antigens } & \multicolumn{3}{|c|}{ Distribution of PFC $\left(\times 10^{6}\right.$ spleen cells $)$ at different time intervals } \\
\hline & & I week & II week & III week \\
\hline 1. & Control fishes & 36.3 & 36.4 & 37.1 \\
\hline 2. & Heat killed bacterial antigen & 10.2 & 11.4 & 12.8 \\
\hline 3. & Whole cell bacterial antigen & 11.2 & 12.1 & 15.8 \\
\hline 4. & Heat killed bacterial antigen with antiserum & 10.7 & 11.6 & 12.9 \\
\hline 5. & Whole cell bacterial antigen with antiserum & 11.1 & 12.3 & 12.7 \\
\hline 6. & Nucleotide antigen & 10.3 & 11.7 & 12.8 \\
\hline
\end{tabular}


pathogen with antiserum treated fishes showed a moderate change in antibody production. Cukrowsha et al. [5] stated that the damage to splenic Ig secreting cell reduces antibody production in fishes. A similar observation was made in the present study, too.

The immune complex of the samples tested was immune enhancer for antibody production. It was expected in animals that were obviously exposed to immune complex that it will resist many intestinal pathogens. Earlier studies reported cross reaction of Escherichia coli with antibody of many other pathogens such as Citrobacter sp., Brucella sp. [6] and Salmonella sp. [7].

B lymphocytes counts using rosette forming assay revealed a significant decrement in pathogens exposed fishes as compared to controls (Table 2). Plate 3.2 depicts the $\mathrm{B}$ cell lymphocytes. Of the two pathogens, a decrement in B lymphocytes was much pronounced in Escherichia coli in the first place and Staphylococcus aureus pathogens had more or less similar impact on B cell estimation. The present study clearly confirms the decrement in B cell number in fish exposed to whole and heat killed pathogens. In this study we conclude impact of whole cell and heat killed pathogenic molecules on the synthesis, proliferation and activation of lymphocytes. Gebel et al. [8], reported that differentiation of $\mathrm{B}$ cell counts is affected by pathogens.

Fishes exposed to pathogenic strains $\left(1 / 10^{\text {th }}\right.$ sublethal concentration) for 3 weeks showed a reduction in PFC. The effect or pathogenic antigens in direct spleenic plaque forming cells ( $1 \mathrm{~g} \mathrm{M}$ producing cells) showed a reduction in the secondary plaque forming cell in the first 3 weeks and a time- and dose-dependent decrease in primary and secondary PFC response. The peak antibody formation occurred in the first week of primary response and in the third week, the secondary response in control as well as in treated animals was seen indicating that there was no delay in antibody formation. Moreover, the present study demonstrates that all pathogenic antigen exposure resulted in a suppression of primary IgM type plaque forming cell in response to antigens in fishes.

Exposure to pathogenic antigens showed a significant decrease in serum antibody titre to different antigens in time-dependent patterns. The serum and response was more evident in pathogenic Staphylococcus aureus treated fishes administered intraperitoneally. However, other antigens reduce $\mathrm{PFC}$ about 3 fold in all the experimental weeks. The reduction in PFC is associated with a decrease in serum antibody response to SRBC in pathogens exposed fishes. Genestier et al. [9] reported that immune-enhancing drugs enrich cell proliferations. B cell proliferations and modification depend on the exposure of antigens. But in the present study, nucleotide (DNA) produces moderate $\mathrm{B}$ cell proliferations. These studies support a foreign substance to be genotoxic and moderate synthesis of DNA in the cell [8].
B cell populations such as potentially auto reactive clones were selectively enumerated at B cell maturation and transforming growth factor of B cell repositories. Pathogens used here were found to be toxic and damage normal activity. This immunoglobulin gene rearrangement in B cell and transforming growth factor- $\beta$ (TGF- $\beta$ ) might be affected by pathogens leading to reduction in $\mathrm{B}$ cell count, such induction by pathogens has been well documented by Kuklin et al. [10].

A remarkable observation enhancement in B cell production due to immune complex of antigens was noted in the present study. The enhancement of this type of immune responses confirms the potential of immune complexes to be used as vaccines.

The authors declare no conflict of interst.

\section{References}

1. Ellis AE (1999) Immunity to bacteria in fish. Fish and Shellfish Immunology 9: 291-308.

2. Talaro KP: Foundations in microbiology. $5^{\text {th }}$ edition, McGraw, New York 2005.

3. Adedeji OB, Okerentugba PO, Onianwa O, Okonko IO (2013): Immune Response of fish to bacterial infections. Researcher 5: 96-103.

4. Michal RD, Priscilla AS (1994): Variation in the antibody response to bovine serum albumin in Oreochromismossambicus (Peters). Ind J Exp Biol 32: 474-477.

5. Cukrowsha et al. [5] (1996)

6. Berry MB, Bundle DR (1990): Antigenic relationship of the lipopolysaccharides of Escherichia hermanii strains with those of Escherichia coli O157: H7. Brucellamelitensisand Brucellaabortus. Infect Immun 58: 1391-1395.

7. Berry WD, Berger-Bachi B, Ayser FH (1986): Additional DNA in methicillin resistant Staphylococcus aureus and molecular cloning of mec-specific DNA. J. Bacteriol 165: 373378.

8. Gebel T, Kevekordes S, Par K, et al. (1997): In vivo genotoxicity of selected Herbicides in mouse bone marrow micronucleus test. Arch Toxicol 71: 193-197.

9. Genestier L, Paillot R, Ferrao C, et al. (1998): Immunosuppressive properties of methotrexate: apoptosis and clonal deletion of activated peripheral T cells. J Clin Invest 102: 322-328.

10. Kuklin NA, Clark DJ, Secore S, et al. (2006): A novel Staphylococcus aureus vaccine: iron surface determinant B induces rapid antibody responses in rhesus macaques and specific increased survival in a murine $S$. aureus sepsis model. Infection and immunity $74: 2215-2223$. 